\title{
Sustainability of the Youth Empowerment Scheme (YES): A Case Study of Agricultural and Rural Management Training Institute
}

\section{Segun-Alalade A.F. ${ }^{1} \quad$ Ibitoye O.M. $^{2} \quad$ Alalade O.A. ${ }^{3^{*}} \quad$ Adesina B.S. $^{4} \quad$ Elisha-Nissi D.O. ${ }^{3}$}

1. Department of Sociology, University of Ibadan, Nigeria.

2. Finance and Supplies Department, Agricultural and Rural Management Training Institute (ARMTI), Ilorin, Nigeria.

3. Extension Management Division, Department of Rural Development and Gender Issues, Agricultural and Rural Management Training Institute (ARMTI), Ilorin, Nigeria.

4. Enterprise Management Division, Department of Rural Development and Gender Issues, Agricultural and Rural Management Training Institute (ARMTI), Ilorin, Nigeria.

\begin{tabular}{l}
\hline ARTICLE INFO \\
\hline Article history \\
Received: 6 May 2021 \\
Accepted: 28 May 2021 \\
Published Online: 31 May 2021 \\
\hline Keywords: \\
Sustainability \\
ARMTI \\
Agriculture \\
YES
\end{tabular}

\begin{abstract}
The study examined the sustainability of youth empowerment scheme using ARMTI as a case study. A three-stage sampling technique was adopted in the selection of 112 respondents for the study using structured questionnaire. Descriptive statistics was used to analyse data. The result of the findings show that the mean age of the respondents was 34.5 . The study revealed more male $(63.4 \%)$ participation in the programme, with majority $(72.3 \%)$ being single. Major benefit derived by respondents were skill acquisition, (98.2\%), positive change in attitude towards agriculture (94.6\%), and access to capital (90.2\%). Inadequate fund or capital support by the government, poor post-empowerment support by the government, and uncertainty over the political environment to support continuity were the major constraints to sustainability of the scheme. There was significant relationship between constraints $(r=0.462 *)$ and perceived sustainability of the youth empowerment scheme. The study concluded that youth empowerment scheme was adjudged sustainable. Government, development experts and donor agencies must ensure that sustainability of the programme is taken into cognizance at every level of the programme and efforts must be put into incorporation of monitoring and evaluation from the beginning so as to prevent wastage of resources.
\end{abstract}

\section{Introduction}

Agriculture has been described as the main stay of the Nigerian economy since independence in 1960, contributing significantly to the gross domestic product of the country (Oyesola and Obabire 2011). Nigeria during this period emerged as one of the world's major producers and exporters of cash crops such as cotton, palm kernel, cocoa, groundnut, hides and skin, and rubber (Afolayan and Ajibade 2012). However, the oil boom of the 1970s badly affected agricultural sector, with oil becoming the main stay of the nation's economy previously dominated by agriculture. (Olajide, Akinlabi and Tijani 2012). It is worthy of note that this economic shift to oil signalled the inception of the myriad of socio-economic challenges faced by Nigeria till date (Adesina, 2013). The challenge of increased youth unemployment could practically be traced to the neglect of agriculture and the over-dependence on oil (Adesina, 2013).

The pathetic state of Nigeria's economy has no doubt led to widespread poverty and youth unemployment becoming

*Corresponding Author:

Alalade O. A.;

segunalalade@gmail.com 
the most daunting development challenges hindering the Nation from achieving sustainable development goals. Evidences abound to prove that this assumption is valid. For example, the works of Olajide, Akinlabi and Tijani (2012); Aiyedogbon and Ohwofasa, (2012); Adesina, (2013); and Oduwole, (2015), reported that poverty rate and youth unemployment are the key factors leading youths to robbery, drug and human trafficking, terrorism, cybercrime, kidnapping, pipeline vandalism, and other social vices thus halting socio-economic development in Nigeria. Thus, in order to get a lasting solution to the challenge of unemployment and poverty rate in Nigeria, the government must aggressively carry out youth empowerment schemes. This is because, youth empowerment programmes offer a good platform for engaging the youths in different vocational training and participation in diverse skill acquisition programmes that could ramify them from social vices while engaging them in meaningful socio-economic developmental and capacity building activities, and social bonding.

Therefore, Nigeria grapples with the problem of unemployment among youths in the country (Abefe-Balogun, 2015), the Federal and State Governments have designed and implemented several empowerment programmes particularly in agriculture to enhance the economic capacity of youths (Umeh and Odo, 2002). Such programmes include but not limited to the Youth Initiative for Sustainable Agriculture (YISA), National Poverty Eradication Programme (NAPEP), Youth Integrated Training Farm (Kwara State), Graduate Farmers Scheme (Osun State), Youth Empowerment Scheme (O-YES) Agricultural Youths Empowerment Scheme (AGRIC-YES), and youth empowerment scheme of Oyo state (YES-O).

This study is principally focused on the Youth Empowerment Scheme (YES), inaugurated by the Agricultural and Rural Management Training Institute in conjunction with the Federal Government of Nigeria in 2013 with the aim of training and empowering unemployed youths in agricultural related business. YES is a federal government sponsored program designed to equip youths with agripreneurship skills which would prepare the beneficiaries with the tools to create job opportunities and become self-reliant after the empowerment cycle. Unfortunately, several studies show that the present empowerment schemes in Nigeria might not yield the expected results if the program content is not designed in a way that would enable the youths to participate effectively in resolving Nigeria's protracted development challenges (Aiyedogbon and Ohwofasa, 2014). Furthermore, experience has shown that government empowerment programmes barely outlive the administration that initiated them. In addition, the nation is currently in a serious economic mess in the form of a dwindling economic fortune, brought about partly by the COVID-19 pandemic. The implication is that the sustainability of the programme could be greatly hampered as a result of the economic downturn. The resultant effects of the dwindling economic fortune is expected to negatively affect government's agricultural empowerment Programmes (Ogunlela, 2015). One therefore begins to wonder how the government will cope with sustaining the programmes in the face of the current economic realities. The need therefore arises to determine whether the YES programme is insulated from other future unforeseen circumstances and unpredicted changes such as market dynamics, regime change, and instability in policies of government, which may occur upon the expiration of the incumbent administration. Evaluating the sustainability of the programme will offer guidance and help to ensure that the overall goal of bringing about a sustainable development in the agricultural sector through youth empowerment is achieved. Going by the foregoing, the study sought to achieve the following objectives;

1. identify the benefits derived from the youth empowerment scheme by the respondents;

2. examine perceived sustainability of the programme and

3. determine constraints to the sustainability of the youth empowerment scheme.

\section{Hypothesis}

$\mathrm{Ho}_{1}$ : There is no significant relationship between benefits, and constraints faced by beneficiaries of the scheme and perceived sustainability of the scheme.

\section{Methodology}

The population for the study comprises all beneficiaries of the youth empowerment scheme from year 2015 through the year 2019. The determination of sampling frame was based on the information gathered from the desk officer of the programme at the Agricultural and Rural Management Training Institute, Ilorin. The table 1 below presents information on the sampling frame.

Table 1. Selection of Respondents for the Study

\begin{tabular}{cccc}
\hline Year & $\begin{array}{c}\text { Sampling frame } \\
\text { of beneficiaries }\end{array}$ & $\begin{array}{c}\text { Beneficiaries randomly } \\
\text { selected at (50\%) each }\end{array}$ & $\begin{array}{c}\text { Number of copies } \\
\text { of questionnaires } \\
\text { retrieved }\end{array}$ \\
\hline 2015 & 52 & 26 & 22 \\
2016 & 48 & 24 & 24 \\
2017 & 45 & 23 & 19 \\
2018 & 53 & 27 & 25 \\
2019 & 49 & 24 & 22 \\
Total & 247 & 124 & 112 \\
\hline
\end{tabular}

Source: Field Survey, 2020

A three-stage sampling technique was used in the selec- 
tion of respondents for the study. The first stage involves the purposive selection of beneficiaries of the programme between the year 2015 and 2019. For the second stage, the list of beneficiaries of the programme was gotten from the desk officer of the programme. From the list, systematic random sampling technique was used to select $50 \%$ of the beneficiaries of the programme in each year under consideration. In all, a total of One Hundred and Twenty-four respondents were selected for the study. However, only One Hundred and Twelve Questionnaires were retrieved, indicating a response rate of $90 \%$. Descriptive and inferential statistics were used to analyze the data collected through questionnaire administration.

Sustainability was considered as perceived sustainability and measured by providing respondents with a set of 26 statements on sustainability in four main domains (economic, political, ownership and technical) using 5-point likert- type scale of strongly agree $=5$, agree $=4$, undecided $=3$, disagree $=2$ and strongly disagree $=1$. Sustainability index was computed and the empowerment scheme was categorised as sustainable and unsustainable using mean $(\overline{\mathrm{x}}=60.5)$ as benchmark. Constraints to sustainability were measured as either a constraint $=1$ or not a constraint $=0$. Mean was obtained and used to rank constraints according to severity.

\section{Results and Discussion}

Results from table 2 reveals that the mean age of respondents was 34.5years, showing that the respondents were indeed in their youthful years, energetic, vibrant and an investment in them is worth it because youths are the future of every society. The result further shows that the programmes in each state captured youths, who are the intended beneficiaries especially within the context of prolonged youth age and postponed transition to adulthood. Youths are generally known for their activeness and energy to which Odubola (2009) asserted that it makes them more viable for agricultural activities.

More males (63.4\%) were involved in the empowerment scheme than the female counterpart $(36.6 \%)$. The result affirms the commonly held notion that agriculture is male dominated, owing to its energy demanding nature. This agrees with the finding of Oladele and Kareem (2003) that males are readily available for energy demanding jobs like agriculture. Majority of the respondents $(64.3 \%)$ were graduates which is understandable considering that the programme was specifically designed to enhance the capacity of graduate youth. However, the inclusion of beneficiaries with secondary education shows that the programme does not discriminate based on someone's educational status. This is also pointing to the fact that many criteria might have been used in the selection of the beneficiaries, with consideration given to some non-graduates

Table 2. Distribution of Respondents' Personal Characteristics $(n=112)$

\begin{tabular}{lcr}
\hline Variable & Frequency & Percentage \\
\hline Age (years) & & \\
20 and below & 4 & 3.60 \\
$21-30$ & 46 & 41.1 \\
$31-40$ & 53 & 47.3 \\
Above 40 & 9 & 8.0 \\
Mean Age & & $\mathbf{3 4 . 5}$ \\
Sex & & \\
Male & 71 & 63.4 \\
Female & 41 & 36.6 \\
Education & & \\
Secondary & 6 & 5.36 \\
Tertiary & 72 & 64.3 \\
Postgraduate & 34 & 30.3 \\
Marital Status & & \\
Single & 81 & 72.3 \\
Married & 31 & 27.7 \\
Membership of Association & \\
Yes & 78 & 69.4 \\
No & 34 & 30.6 \\
& $\mathbf{1 1 2}$ & $\mathbf{1 0 0 . 0}$ \\
\hline
\end{tabular}

Source: Field Survey, 2020

\subsection{Benefits derived by respondents from the pro- grammes}

Table 3 shows that while $98.2 \%$ of the respondents indicated skill acquisition as one of the key benefits derived from the scheme. The result is not surprising considering that participants are taught requisite farming skills during the training exercises with relevant backup practicals through which they are empowered for self-sustenance. All agricultural activities inculcates practical training to the recipients, thus acquisition of skill in this programme will make respondents to be self-sufficient in all areas of life thus encouraging sustainability of the programme. The resultis consistent with Tijani (2018), who reported that training through skill acquisition and capacity building programmes will enhance the sustainability of the youths in different fields of endeavour. Agriculture is widely known to provide employment to people, to which $88.4 \%$ of the participants attested to. Employment opportunities generated during the training programme will no doubt traslate to a means of alleviating poverty to which $79.5 \%$ of the respondents agrees with. Hence, agriculture is a field of study that prepare people for gainful employment and enables one to carry out successfully a socially "useful occupation.

Table 3 also shows that $90.2 \%$ of the respondents indicated access to capital as one of the benefits of the scheme. This is understandable considering the fact that the scheme works in synergy with the Bank of Agriculture so as to help trained youths get access to loan with single digit interest rate after submitting a business plan carefully examined by 
facilitators in ARMTI. The government helps these youths open an account with the Bank of Agriculture, depositing Two Hundred Thousand Naira (\#200,000.00) each into these accounts. These enables the beneficiaries to then access loan to the tune of Two Million Naira ( $\# 2,000,000.00)$. For some set however, the government simply gave out starter packs consisting of One Hundred Laying birds, feeds, drugs, and a cash of One Hundred Thousand Naira (\#100,000.00). Other benefits from the scheme are linkage to market (70.5\%) and linkage to input suppliers $(81.2 \%)$.

Table 3. Distribution of respondents accroding to benefits derived from the scheme

\begin{tabular}{|c|c|c|}
\hline Benefits Derived & Percentage & \\
\hline Poverty alleviation & 89 & 79.5 \\
\hline Access to capital & 101 & 90.2 \\
\hline Skill acquisition & 110 & 98.2 \\
\hline Positive change in attitude towards agriculture & 106 & 94.6 \\
\hline Provision of job opportunities & 99 & 88.4 \\
\hline Boost self-esteem and confidence & 84 & 75.0 \\
\hline Linkage to market & 79 & 70.5 \\
\hline Linkage to input supplier & 91 & 81.2 \\
\hline
\end{tabular}

\section{Multiple responses}

Source: Field survey, 2020

\subsection{Perceived sustainability of the programme}

The result from table 4 reveals the beneficiaries' perception of the sustainability of youth empowerment scheme by ARMTI. As per economic sustainability, statement on access to factors of production such as land, capital and inputs had the highest mean $(\overline{\mathrm{x}}=3.90)$ while the statement that some beneficiaries seem to be after the grants promised by the government rather than being trained to be self-reliant had the lowest mean $(\bar{x}=3.22)$. Such set of beneficiaries can be likened to free-riders who, according to Albert (2000), are usually the unintended beneficiaries of a socially provided public good. These people are usually seen channelling any grant received into other non-agricultural ventures.

Table 4 also shows the result on the perception of beneficiaries on the political sustainability of the scheme. It was found that the statement that more relevant government policies need to be enacted to support the programme for its survival had the highest mean score $(\overline{\mathrm{x}}=4.32)$. This result is in tandem with Odubola (2009) who pointed out uncertainty over the political environment to support programme continuity in the country, a trend that keeps recurring as a result of a systemic policy problem and continues to be a bane to effective agricultural development.

As per ownership sustainability, table 4 reveals that the statement on beneficiaries benefitting more when there is a positive programme outcome had the highest mean score $(\overline{\mathrm{x}}=3.90)$. This will no doubt give beneficiaries the impression that they are major stakeholders in the scheme. This would in turn make them work tireless towards ensuring that the objectives of the scheme are achieved.

Furthermore, table 4 shows the perception of respondents on the technical sustainability of the scheme. It was revealed that statements that the beneficiaries could take advantage of cooperatives formed to access more government

Table 4. Perceived Sustainability of the Youth Empowerment Scheme

\begin{tabular}{|c|c|}
\hline Perceived Sustainability & Mean \\
\hline \multicolumn{2}{|l|}{ Economic sustainability } \\
\hline $\begin{array}{l}\text { 1. Expansion for increased profitability may not be possible in my } \\
\text { business enterprise without continuous help from government. }\end{array}$ & 3.78 \\
\hline $\begin{array}{l}\text { 2. My enterprise may be incapable of meeting my needs if there is } \\
\text { no further support from government. }\end{array}$ & 3.82 \\
\hline $\begin{array}{l}\text { 3. Some beneficiaries seem to be after the grants promised by the } \\
\text { government rather than being trained to be self-reliant. }\end{array}$ & 3.22 \\
\hline $\begin{array}{l}\text { 4. Access to factors of production such as land, capital and inputs } \\
\text { could be a challenge if government fails to provide them. }\end{array}$ & 3.90 \\
\hline \multicolumn{2}{|l|}{ Ownership sustainability } \\
\hline $\begin{array}{l}\text { 5. The government is willing to bear the loss in case of negative } \\
\text { outcomes. }\end{array}$ & 2.81 \\
\hline 6. The programme appears to benefit all, despite party affiliations. & 2.22 \\
\hline 7. Beneficiaries benefit more when there is positive result. & 3.90 \\
\hline $\begin{array}{l}\text { 8. It appears beneficiaries cannot make decision on the enterprise } \\
\text { without approval from the government }\end{array}$ & 1.90 \\
\hline 9. The programme may be a sheer waste of time of beneficiaries & 3.12 \\
\hline
\end{tabular}
as people view the programme as political campaign rather than to empower them

Technical sustainability

10. There seems to be adequate resources to empower the beneficia- 2.60 ries.

11. Infrastructures appear to be available to be used by beneficiaries. 2.08

12. There ought to be a special task force established to recommend 4.08 areas requiring improvement in the programme.

13. The beneficiaries could take advantage of cooperatives formed to 4.11 access more governmental support

14. The programme could have done better in equipping beneficia- $\quad 3.89$ ries with the skills to undertake agricultural projects.

15. The experience gathered looks insufficient to manage and main- $\quad 3.74$ tain a bigger farm enterprise

16. The programme may not achieve set objectives as it is a means $\quad 3.43$ to perpetrate corruption by the federal government

17. Beneficiaries seem capable to source market for produce if $\quad 2.01$ government fails to buy.

18. Non-governmental organisations (NGOs) should get more $\quad 4.04$ involved in the programme.

Political sustainability

19. There seem to be laws in place to ensure the continuity of the $\quad 2.90$ programme from one regime to another.

20. Government seems committed to building on the successes of $\quad 3.99$ the programme.

21. The government seems to be fulfilling all its promises, to ensure 2.94 success of the programme.

22. The programme may be scrapped as soon as the incumbent $\quad 3.52$ government leaves office.

23. The programme might fail because many of the achievements $\quad 3.58$ claimed are untrue.

24. The programme is seen to be more of political propaganda; therefore, it may be discontinued by next government.

25. Constitutional amendment processes are required to scrap the $\quad 3.12$ programme

26. More relevant government policies need to be enacted to support 4.32 the programme for its survival.

Source: Field survey, 2020 
support $(\overline{\mathrm{x}}=4.11)$ had the highest mean, with statement that there ought to be a special task force established to recommend areas requiring improvement in the programme $(\overline{\mathrm{x}}=$ 4.08 ) and statement that non-governmental organisations (NGOs) should get more involved in the programme $(\overline{\mathrm{x}}=$ $4.04)$ ranking $2^{\text {nd }}$ and $3^{\text {rd }}$ respectively.

Table 5. Categorisation of Perceived Sustainability of the Youth Empowerment Scheme

\begin{tabular}{ccccc}
\hline Sustainability & Percentage & Minimum & Maximum & Mean \\
\hline $\begin{array}{c}\text { Unsustainable } \\
\text { (below mean) } \\
\begin{array}{c}\text { Sustainable } \\
\text { (mean and above) }\end{array}\end{array}$ & 36.6 & 47.0 & 88.5 & 64.5 \\
\hline
\end{tabular}

Field survey, 2020

\subsection{Constraints to the sustainability of the scheme}

Table 6 reveals inadequate funding/support by the government as the major constraint affecting the sustainability of the scheme. This is because fund is essential to the success of any project/activities without which the empowerment programme will drag, there will be lack of equipment or facilities to organise the training effectively, payment of trainers and money to support the trainees to take-off, put what was learnt into practice and this will greatly affect sustainability of the programme. Other major constraints are: poor post-empowerment support by the government; uncertainty over the political environment to support continuity; inadequate monitoring and evaluation of the beneficiaries; negative attitude of other beneficiaries during training; and Favouritism in the process of selecting beneficiaries as they ranked $2^{\text {nd }}, 3^{\text {rd }}, 4^{\text {th }}, 5^{\text {th }}$, and $6^{\text {th }}$ respectively. This result is consistent with the findings of Tijani (2018) who pointed out inadequate funding, uncertainty over the political environment to support continuity of programmes and regime change as major constraints militating against the sustainability of government programmes. In Nigeria in particular, regime change implies non funding or scraping of programmes initiated by the previous government no matter how laudable they are thus, resulting in collapse of such programmes. Hence, lack of continuity in government programme(s) means unsustainability of the programme. These findings are quite germane as Salako and Badmus (2014) stated that most government's empowerment programmes often fail to achieve the targeted goal due to inadequate funding. Relating to policy issue, International Institute of Tropical Agriculture (IITA) (2005) advanced that overtime policy instability, policy inconsistencies, narrow base of policy formulation, poor policy implementation and weak institutional framework for policy coordination have remained constraints to effective agricultural development. All the constraints identified by the respondents revolved round the issue of funding such as monitoring and evaluation that involve cost of transportation, feeding and sometimes accommodation. In line with these, Tijani (2018) asserted that government does not usually give programme participants support such as grant or loan to establish their own enterprises and also fail to provide an enabling environment after conclusion of programmes. Additionally, it is reported that government employment programmes do not always have adequate supervision (Akinremi and Sonaiya, 2009), which results in poor service delivery.

\subsection{Test of hypothesis}

Table 7 shows that a significant relationship exist between constraints and perceived sustainability of the youth empowerment scheme. By implication, constraints such as insufficient funding, poor post-empowerment support, uncertainty over the political environment to support continuity amongst others will threaten the sustainability of the programme. For instance, insufficient fund can affect acquisition of inputs, hiring of labour, transportation of output to the market thereby threatening involvement and or sustainable production. This is supported by the findings of Adekunle, Adefalu, Oladipo, Adisa and Fatoye (2009) that several constraints faced by the youths are responsible for their low level of involvement in agriculture. Also, table 7 further shows that sustainability of

Table 6. Constraints to the Sustainability of the Scheme

\begin{tabular}{|c|c|c|}
\hline Constraints & Mean & Rank \\
\hline Negative attitude of other beneficiaries during training & 0.62 & $5^{\text {th }}$ \\
\hline Inadequate fund or capital support by the government. & 0.87 & $1^{\text {st }}$ \\
\hline Programme is fraught with excessive bureaucracy & 0.51 & $7^{\text {th }}$ \\
\hline Poor response of agricultural knowledge and information system to beneficiaries' challenges & 0.48 & $10^{\text {th }}$ \\
\hline Inability to benefit from Agricultural Knowledge and Information Systems & 0.42 & $11^{\text {th }}$ \\
\hline Uncertainty over the political environment to support continuity & 0.72 & $3^{\text {rd }}$ \\
\hline Poor post-empowerment support by the government & 0.77 & $2^{\text {nd }}$ \\
\hline Inadequate access to agricultural knowledge and information system & 0.49 & $8^{\text {th }}$ \\
\hline Lack of market for produce as envisaged & 0.49 & $8^{\text {th }}$ \\
\hline Favouritism in the process of selecting beneficiaries & 0.58 & $6^{\text {th }}$ \\
\hline
\end{tabular}

Source: Field survey, 2020 
the scheme is dependent on the benefits derived by the respondents. Loan/credit to set up the business as well as ready market for the output can serve as incentives for continuous involvement in the programme. This is in line with Ogunleye et al (2014) that the benefit offered by any programme will determine its sustainability.

Table 7. Relationship between benefits, and constraints faced by beneficiaries of the scheme and perceived sustainability of the programme.

\begin{tabular}{llc}
\hline Variable & r-value & p-value \\
\hline Benefits & $0.382^{*}$ & 0.000 \\
Constraints & $0.462^{*}$ & 0.002 \\
\hline
\end{tabular}

$* P \leq 0.05$

\section{Conclusion and Recommendations}

The study concluded that the youth empowerment scheme from ARMTI was not without its shortcomings as identified by the beneficiaries. However, majority of the beneficiaries of the scheme agreed the training programme was successful. The programme's aim of imparting skill, changing of attitude of the youth to agriculture as a vocation was significantly achieved. The programme was laudable and impactful, and respondents found the Youth Empowerment Scheme to be sustainable based on economic, political, technical and ownership criteria of International Fund for Agricultural Development (IFAD 2007).

In lieu of the foregoing, the following recommendations were made:

- Subsequent programme should be gender sensitive in order to balance male to female enrolment.

- Government, development experts and donor agencies must ensure that sustainability of programme is taken into cognizance at every level of the programme and efforts must be put into incorporation of monitoring and evaluation from the beginning so as to prevent wastage of resources.

- There is an urgent need to ensure appropriate legislation so as to insulate the programme from political shocks that may come as a result of change in government.

\section{References}

[1] Adesina O.S (2013). Unemployment and security Challenges in Nigeria. International Journal of Humanities and Social Science, Vol. 3 No. 7.

[2] Abefe-Balogun, B. (2015). Osun State Youth Empowerment Scheme: A key to Sustainable Development. Journal of Economics and Sustainable Development 6(9): 260-267.
[3] Afolayan O.S.m and Ajibade L.T (2012). Temporal Variation in Perennial Cash Crops Production in Ondo State, Nigeria. Asian Journal of Natural and Applied Sciences, Vol. 1 No. 3.

[4] Aiyedogbon and Ohwofasa, (2012): Role of youths in agriculture development in Makurdi Local Government Area, Benue State, Nigeria. Journal of Agricultural Extension, vol. 13, pp. 40-45.

[5] Akinremi, S. and Sonaiya, A. (2009). Rural-Urban Socio Economic Link; The Example of Migration is Modern Migration in West Africa. Oxford University of Press, London, p129.

[6] International Institute of Tropical Agriculture (IITA) (2005). Agriculture in Nigeria: Identifying Opportunities for Increased commercialization and investment.

[7] Odubola, P. (2009). Prospecting for Strategic Advantage: The Proactive Entrepreneurial Personality and Small Firm Innovation. Journal of Small Business Management, New York. Vol 40.pp. 85-97.

[8] Oduwole, T. A. (2015). Youth Unemployment and Poverty in Nigeria. International Journal of Sociology and Anthropology Research. Vol.1, No. 2, European Centre for Research Training and Development UK (www.eajournals.org).

[9] Ogunlela, J. (2015). Perspective: Putting Osun State's Salary Challenge in a Fairer Context. The Nation Newspaper, Nigeria. Retrieved online from www.the nation online ng.net July 3rd 2015.

[10] Oladele, I. O., and Kareem, A. I. (2003). Adoption Rate and Continued Use of Selected Arable Crop Technologies among Farmers in Oyo State. Journal of Food, Agriculture and Environment. 3: 291-294

[11] Olajide O.T, Akinlabi B.H, Tijani A.A (2012). Agriculture Resource and Economic Growth in Nigeria. European Scientific Journal. Vol. No. 22.

[12] Oyesola O.B and Obabire I.E (2011). Farmers' Perceptions of Organic Farming in Selected Local Government Areas of Ekiti State, Nigeria. Journal of Organic Systems, 6 (1).

[13] Salako, A. and Badmus, O. P. (2014). Strategic Management of Small firms in Hostile and Benign Environments. Strategic Management Journal, 10, 75-87.

[14] Tijani, S. A. (2018): Sustainability of the Youth Agriculture Empowerment Programmes in Osun and Oyo States, Nigeria. Nigerian Journal of Rural Sociology Vol. 18, No. 2, 2018.

[15] Umeh, G. N., and Odo, B. I. (2002). Profitability of Poultry Production among School Leavers in Anocha Local Government Area of Anambra State, Nigeria. Nigeria Journal of Animal Production 29: 76-80. 